\title{
Protective effect of rutin on the antioxidant genes expression in hypercholestrolemic male Westar rat
}

\author{
Salem S Al-Rejaie, Abdulaziz M Aleisa, Mohamed M Sayed-Ahmed, Othman A AL-Shabanah, \\ Hatem M Abuohashish, Mohammed M Ahmed, Khaled A Al-Hosaini and Mohamed M Hafez
}

\begin{abstract}
Background: High-cholesterol diet (HCD) increases the oxidative stress in different tissues leading to many diseases. Rutin (RT) is a natural flavonoid (vitamin p), which possesses an antioxidant activity with protective potential. The present study aimed to examine the potential effects of rutin on hypercholesterolemia-induced hepatotoxicity in rat.

Methods: Male Wistar rats were divided into four groups: Gl) control (Rat chow), GII) Rutin (0.2\% in rat chow), GIII) HCD ( $1 \%$ cholesterol and $0.5 \%$ cholic acid in rat chow) and GIV) rutin $(0.2 \%)+$ HCD.

Results: Rutin in combination with HCD induced a significant protective effect against the hepatotoxicity by reducing the plasma level of alanine transaminase (ALT), aspartate aminotransferase (AST), triglyceride (TG), total cholesterol (TC), and low-density lipoprotein (LDL). The HCD (GII) showed a decrease in glutathione peroxidase (GPx), glutathione reductase (GR) and increase in glutathione $S$ transferase a (GSTa), sulfiredoxin-1(Srx1), glutamate-cysteine ligase (GCL) and paraoxonase-1(PON-1) genes expression levels.

Conclusion: Treatment with rutin reversed all the altered genes induced by HCD nearly to the control levels. The present study concluded that the HCD feedings altered the expression levels of some genes involved in the oxidative stress pathway resulting in DNA damage and hepatotoxicity. Rutin have a hepatoprotective effect through the mechanism of enhancing the antioxidant effect via amelioration of oxidative stress genes.
\end{abstract}

Keywords: Hypercholesterolemic liver, Rutin, Oxidative stress genes, Real time PCR

\section{Background}

Hypercholesterolemia is considered as one of the most familiar metabolic disorders and it is closely associated with obesity, diabetes mellitus, and several other metabolic syndromes $[1,2]$. It can eventually lead to nonalcoholic fatty liver disease (NAFLD) by depositing the lipids and triglycerides in liver which is usually progress to nonalcoholic steato-hepatitis (NASH), cirrhosis, liver failure and hepatocellular carcinoma [3,4]. NAFLD is characterized by destruction in liver $n-6$ and $n-3$ longchain polyunsaturated fatty acids [5,6]. A major factor associated with these liver fatty acids depletion in obesity is the development of prolonged oxidative stress, which

\footnotetext{
* Correspondence: mohhafez_2000@yahoo.com

Department of pharmacology and toxicology; College of pharmacy, King Saud University, Riyadh, Kingdom of Saudi Arabia
}

may be compounded by defective desaturation activity and dietary imbalance, promoting hepatic steatosis $[6,7]$. Earlier studies demonstrated that, even short exposure to HCD is capable of inducing hypercholesterolemia and is significantly associated with oxidative stress [8].

Obesity is increasing worldwide especially in places with high dietary fat intake and is associated with lot of complications including NAFLD [9]. NAFLD is a common disease with an estimated prevalence in unselected population of developed nations around 20-30\% [10]. From last three decades, Saudi Arabia has been undergoing massive developments. These developments are causing drastic changes in lifestyles and dietary habitats, like many other developed societies some of these changes tremendously increasing physical disorders such as obesity and NAFLD. The prevalence of overweight in 
Saudi Arabia is 36.9\% and more prevalent in males (42.4\%) than females (31.8\%) [11] and recently Al-hamoudi et al., reported prevalence of NAFLD is around 17\% in Saudi population [12].

Accumulation of lipid in hepatocytes may cause a dysfunction in the synthesis of fatty acids. Transcription factors such as sterol-regulatory-element-binding protein-1c (SREBP) and peroxisome proliferator-activated receptor alpha (PPARs) promote hepatic fatty acid synthesis. Long chain polyunsaturated fatty acids and acyl-CoAs, are metabolic regulators of many transcription factors that motivate the liver lipid metabolism. Fatty acids induce changes in the activity of four transcription factor families: PPARs, LXRs, hepatic nuclear factor 4 , and SREBP $[13,14]$. Downregulation of gene expression by fatty acids would be restricted to polyunsaturated fatty acids, but the upregulation would be independent of the saturation [15]. These Differences might involve differential metabolism (oxidative pathways, kinetics etc.) and selective transport of fatty acids to the nucleus. Polyunsaturated fatty acids regulates the genes involved in fatty acid oxidation such as PPARa target genes in which suppress SREBP1c activity, leading to a reduction in liver triacylglycerol content [16]. The liver is a major source of newly synthesized cholesterol. Cholesterol can be derived from newly-absorbed cholesterol, peripheral tissues and cholesterol synthesized within liver. Cholesterol taken up by the liver is in the form of cholesterol esters [17] which can be either stored as esters or hydrolyzed to free cholesterol [18].

Oxidative stress is highly correlated with a wide variety of inflammatory, cancer, brain disorders, and metabolic disease states, including obesity $[19,20]$. It is highly correlated with cumulative damage done by reactive oxygen species (ROS) and reactive nitrogen species (RNS) inadequately neutralized by antioxidants mechanisms [21,22]. It has been shown that free radicals may adversely affect cell survival through the oxidative damage of lipid, protein, and irreversible DNA modification [23,24]. Damage, at the cellular level by oxidants, is attenuated by antioxidant enzyme [25]. Furthermore oxidative damage is aggravated by the decrease in antioxidant enzymes activities which acts as a free radical scavengers in conditions associated with oxidative stress [26]. Superoxide dismutase is one of the major enzymatic antioxidant mechanisms against superoxide radical, prevents liver toxicity induced by oxidative stress [27]. Catalase and GSHPx catalyze dismutation of the superoxide anion $\left(\mathrm{O}_{2}-\right)$ into hydrogen peroxide $\left(\mathrm{H}_{2} \mathrm{O}_{2}\right)$ which then converting $\mathrm{H}_{2} \mathrm{O}_{2}$ to water thus providing protection against ROS [28]. The reduction in activity of these enzymes may be caused by the increase in free radical induced by $\operatorname{HCD}[29,30]$. Paraoxonase (PON1) is another antioxidant enzyme closely associated with high-density lipoproteins, which detoxifies lipid peroxides, and is widely distributed in many tissues, such as liver [31]. Sulfiredoxin-1 enzyme, belongs to the family of oxidoreductases, catalyzes reduction of cysteine sulfinic acid to sulfenic acid in oxidized proteins and protects them from inactivation [32]. Glutamate-cysteine ligase, composed of catalytic subunit (called GCLC) and regulatory subunit (called GCLM), is important for GSH biosynthesis in combating a variety of oxidative stressrelated complications, thereby activating the body's own protective response [33].

Flavonoids are polyphenolic compounds found in plants and have an important role in detoxification of free radicals [34]. Rutin, flavonoid glycosides, possesses different protective effects such as hepatoprotective against carbon tetrachloride ( $\mathrm{CCl} 4)$-induced liver injuries in rats, ischemia/reperfusion-associated hemodynamic alteration through antioxidant activity [35-39]. It has an inhibitory effect against membrane lipid peroxidation and oxidative stress-mediated diseases [40]. In order to find out the possible mechanisms mediating the antioxidant effect of RT, the present study evaluate its effect on gene expression of hepatic antioxidant enzymes in male Wistar rats fed with HCD as animal models for NAFLD.

\section{Methods}

\section{Animals used}

Twenty four young male Wistar albino rats six weeks old with average body weight 80-100 gms, were obtained from the Animal Care Center, College of Pharmacy, King Saud University, Riyadh, Saudi Arabia. The animals were acclimatized to laboratory condition prior ten days to the experiment. They were fed on Purina rat chow diet (Manufactured by Grain Silos \&Flour Mills Organization, Riyadh, Saudi Arabia) and water ad libitum and were maintained under standard conditions of temperature $\left(22 \pm 1^{\circ} \mathrm{C}\right)$, humidity $(50-55 \%)$ and a $12 \mathrm{~h}$ light/dark cycles. All methods including euthanasia procedure were conducted in accordance with Guide for care and use of laboratory animals, institute for laboratory animal research, National Institute of Health (NIH publication No. 80-23; 1996) and it has approved by Research Ethics Committee of Excremental Animal Care Center, College of Pharmacy, King Saud University, Riyadh Saudi Arabia.

\section{Dietary protocol and experimental groups Dietary protocol}

Experimental diets were prepared in pellet form by adding $0.2 \%$ rutin (RT) [41] (power, sigma, USA) or $1 \%$ cholesterol $+0.5 \%$ cholic acid (HCD) [42] or $0.2 \% \mathrm{RT}+$ $1 \%$ cholesterol $+0.5 \%$ cholic acid $(\mathrm{RT}+\mathrm{HCD})$ in rat chow powder. Rat chow was used as normal diets and was prepared weekly and shade dried. 


\section{Experimental group}

The Animals were randomly divided into 4 groups of 6 rats in each as follows:

$$
\begin{aligned}
& \text { Group (I): Animals received rat chow only and } \\
& \text { considered as control. } \\
& \text { Group (II): Animals received rat chow }+0.2 \% \text { rutin } \\
& \text { (RT) } \\
& \text { Group (III): Animals received rat chow }+\{1 \% \\
& \text { cholesterol }+0.5 \% \text { cholic acid }\}(\mathrm{HCD}) \\
& \text { Group (IV): Animals received rat chow }+0.2 \% \text { rutin } \\
& \text { (RT) }+\{1 \% \text { cholesterol }+0.5 \% \text { cholic acid }\} \\
& \text { (HCD). }
\end{aligned}
$$

The experimental diets were supplemented for 6 consecutive weeks. During whole experimental period, all groups of animals were kept on free access to food and water. At end of the experiment, animals were sacrificed by decapitation and the trunk blood was collected in heparinized tubes. Liver tissues were rapidly excised, weighed and kept in $-80^{\circ} \mathrm{C}$ until used. Plasma samples were collected after centrifugation at $1252 \mathrm{~g}$ for $15 \mathrm{~min}$ and kept in $-20^{\circ} \mathrm{C}$ until used.

\section{A-Bioassay measurments}

I- Blood chemistry Plasma levels of aspartate aminotransferase (ALT), alanine aminotransferase (ALT), total cholesterol (TC), triglyceride (TG), high density lipoprotein (HDL), and low density lipoprotein (LDL) were estimated by using commercially available diagnostic kits (Human, Wiesbaden, Germany).

II- Estimation of Malondialdehyde (MDA) in liver The method described by Ohkawa et al., [43] was used to determine MDA concentration in liver. Briefly, $200 \mathrm{mg}$ of liver tissues were homogenized in aqueous $0.15 \mathrm{M} \mathrm{KCl}$ solution to give $10 \%$ homogenate. One $\mathrm{ml}$ of homogenate was then mixed with one $\mathrm{ml}$ of $10 \%$ trichloroacetic acid (TCA) and centrifuged at $704 \mathrm{~g}$ for $15 \mathrm{~min}$. one $\mathrm{ml}$ of supernatant was suspended into one $\mathrm{ml}$ of $0.67 \%$ 2 -thiobarbutaric acid. Sample tubes were then placed into a boiling water bath for $15 \mathrm{~min}$. Samples were allowed to cool down at room temperature followed by centrifugation at $704 \mathrm{~g}$ for $15 \mathrm{~min}$. The optical density of the clear pink supernatants was measured at $532 \mathrm{~nm}$ by using spectrophotometer (LKB-Pharmacia, Mark II, Ireland).

III-Estimation of (Glutathione) GSH levels in liver The concentration of GSH was determined as described by Sedlak and Lindsay [44]. Briefly, 200 gm from liver tissue were dissected out and homogenized in ice-cold $0.02 \mathrm{M}$ ethylenediaminetetraacetic acid (EDTA). An aliquots of $0.5 \mathrm{ml}$ of tissue homogenate was mixed with $0.2 \mathrm{M}$ Tris buffer, $\mathrm{pH} 8.2$ and $0.1 \mathrm{ml}$ of $0.01 \mathrm{M}$ Ellman's reagent, [5,5'-dithiobis-(2-nitr-benzoic acid)] (DTNB). Each sample tube was centrifuged at $704 \mathrm{~g}$ at room temperature for 15 min the absorbance of the clear supernatant was measured using spectrophotometer (LKB-Pharmacia, Mark II, Ireland) at $412 \mathrm{~nm}$.

IV-Assessment of plasma hydrogen peroxide concentration Plasma $\mathrm{H}_{2} \mathrm{O}_{2}$ concentration levels were measured by BioVision assay kit (BioVision, CA, USA). The principles based on the present of horse radish peroxidase, the OxiRed probe react with $\mathrm{H}_{2} \mathrm{O}_{2}$ to produce product with color that can be measure.

\section{$B$ - Assessment of gene expression level (GPX, GR, Srx1, GCL, PON-1 and GST-a genes) by real time PCR in liver tissues}

\section{I- Total RNA extraction}

Total RNA were extracted from liver using RNA Mini kit (Bioline, Taunton,USA) according to the manufacturer's protocol. The quantity and integrity of total RNA were characterized using a UV spectrophotometer (Nanodrop 8000 Thermo Scientific, USA) and ethidium bromide stained agarose gel. The isolated RNA has an A 260/280 ratio of 1.9-2.0.

II- cDNA synthesis and real time PCR methods First-strand cDNA was synthesized from $1 \mu \mathrm{g}$ of total RNA by reverse transcription with a SuperScript ${ }^{\text {mm }}$ first-strand synthesis system kit (Invitrogen, CA, USA), according to the manufacturer's instructions. Real time PCR using $\triangle \triangle C T$ method was done according to previous study [45]. We used GAPDH gene as housekeeping gene. All primers used in this study were synthesized in Metabion Company (Metabion international AG, Germany) and listed in Table 1.

\section{Statistical analysis}

Differences between obtained values (mean \pm SEM, $\mathrm{n}=6$ ) were carried out by one way analysis of variance followed by the Tukey-Kramer multiple comparison. The differences were considered statistically significant at $\mathrm{P}<0.05$.

\section{Results}

Liver enzymes, ALT and AST levels in plasma were used as biochemical markers for the early acute hepatotoxicity. Rats fed with HCD for 6 weeks had significant increase in of AST and ALT levels $(\mathrm{p}<0.001)$ compared to control group. Rutin supplementation alone showed no significant changes in biochemical markers. However, administration 
Table 1 Showing primers and probe used

\begin{tabular}{|c|c|c|c|}
\hline Gene name & Forward primer & Reverse primer & Probe \\
\hline Glutathione peroxidase & 5'-GGTGTTCCAGTGCGCAGAT-3' & 5'-AGGGCTTCTATATCGGGTTCGA-3' & FAM-CAGCAGGCGCTTTCGCACCA-TAMRA \\
\hline Glutathione reductase & 5'-TGAGCCGCCTGAACAACA-3' & 5'-TTGCGTAGCCGTGGATGAC-3' & $\begin{array}{l}\text { FAM-CCAAAACAATTTAACCAAGTCCCACATCGA } \\
\text { TAMRA }\end{array}$ \\
\hline $\begin{array}{l}\text { Glutathione } s \\
\text { transferase - } a\end{array}$ & 5'-AATATGTCCCCCAGACCAAAGA-3' & 5'-GGCAGGCAAGTACCGGTTT-3' & FAM-CGCCTTGGCAAAAGACAGGACCA-TAMRA \\
\hline $\begin{array}{l}\text { Glutamate-cysteine } \\
\text { ligase }\end{array}$ & 5'CAGAGTATGGGAGTTACATGATTGAAG-3' & 5'-TGTGTTGAACTCGGACATCGTT-3' & FAM-ACACCTGGCCAGCCGTACGGAG-TAMRA \\
\hline Paraoxonase-1 & 5'-TGAGAGCTTCTATGCCACAAATG-3' & 5'-CCATGACAGGCCCAAGTACA-3' & $\begin{array}{l}\text { FAM-TTTTGCTGACCCATACTTACGGTCCTGG- } \\
\text { TAMRA }\end{array}$ \\
\hline Sulfiredoxin-1 & 5'-AATCCCCAACCCCTGACTTT-3' & 5'-TGAACTGACCAGTGGAGACACAGT-3' & FAM-ACAAGGTTTCTTCAGCCCCGGTGC-TAMRA \\
\hline GAPDH & 5'- TGGCCTCCAAGGAGTAAGAAAC -'3 & 5'- GGCCTCTCTCTTGCTCTCAGTATC -'3 & FAM- CTGGACCACCCAGCCCAGCAA-TAMRA \\
\hline
\end{tabular}

of rutin in combination with HCD resulted in reversal of hepatic damage biomarker induced by HCD to normal values (Table 2). Lipid parameters of HCD fed rats including TG, TC and LDL levels were significantly increased in plasma by $48 \%, 89 \%$ and $67 \%$ respectively and significantly decreased the HDL levels by $17 \%$ compared to control group. Rutin supplementation in combination with HCD, significantly decreased $\mathrm{TC}$ and LDL levels compared to HCD group. On the other hand there is no effect on TG, TC, HDL and LHL was observed on the supplementation of RT alone (Table 2).

The effect of HCD, rutin and their combination on the oxidative stress biomarkers and indices of lipid peroxidation, MDA, H2O2 and GSH were shown in Table 3. The HCD feeding was resulted significant increase in liver MDA by $23 \%$ and in plasma $\mathrm{H}_{2} \mathrm{O}_{2}$ by $354 \%$, and decrease in hepatic GSH level by $17 \%$ compared to the control group. Rutin administration in combination with $\mathrm{HCD}$ resulted in a significant decrease in the levels of MDA and H2O2 and increase the hepatic level of GSH compared to HCD group.

The present results showed an insignificant decrease by $23 \%$ in the expression of GPX gene and significant decrease by $65 \%$ in GR genes in rats fed with HCD compared to control group (Figure 1A \& B). Interestingly, administration of rutin in combination with HCD resulted in a significant increase the expression of these genes by $245 \%$ and $441 \%$ compared to HCD group and by $166 \%$ and $90 \%$ compared to control group respectively.
The expression of Glutathione $S$ transferase $\alpha$, paraoxonase-1, sulfiredoxin and glutamate-cystein ligase were significantly increased by $220 \%, 160 \%, 250 \%$ and $230 \%$ respectively, in HCD fed rats compared to the control group (Figures 2A, B, C \& D). The rutin supplementation with $\mathrm{HCD}$ resulted in significant decrease in the expression of Glutathione $S$ transferase $\alpha, \mathrm{PON}-1$ and sulfiredoxin genes by $63 \% 130 \%$ and $54 \%$ respectively and an insignificant decrease in the glutamate-cystein ligase gene expression by $45 \%$ as compared with HCD group.

\section{Discussion}

Obesity is a risk factor for many diseases such as cardiovascular [46] and liver diseases [3,4]. Rat models fed with $\mathrm{HCD}$ can be used as model of the human obesity syndrome $[47,48]$. The present study examined the hepatoprotective effect of rutin against hepatotoxicity induced by HCD in rat model and demonstrated that HCD caused hepatotoxicity through increasing plasma levels of liver enzymes ALT and AST. In agreement with earlier studies, the elevated ALT and AST levels are attributed to hepatic damage that may contribute to oxidative stress unbalance $[49,50]$. Rutin has reduced the oxidative stress in liver, kidney, and brain tissues of rats $[51,52]$. As a result of rutin supplementation, ALT and AST levels were lowered that led to decrease the hepatic damage caused by HCD feeding. The present results showed that rutin can protect hepatocyte against toxicity induced by HCD.

Table 2 Effect of High cholesterol diet, rutin and their combination on plasma levels of AST, ALT, TG, TC, HDL and LDL

\begin{tabular}{ccccccc}
\hline Group & AST (U/L) & ALT (U/L) & Triglycerides (mg/dl) & Total cholesterol (mg/dl) & HDL (mg/dl) & LDL (mg/dl) \\
\hline Control (rat chow) & $35.64 \pm 1.52$ & $22.76 \pm 0.84$ & $63.03 \pm 5.99$ & $66.67 \pm 4.25$ & $29.91 \pm 1.32$ & $48.32 \pm 2.32$ \\
$\quad$ Rutin (0.2\%) & $34.40 \pm 0.79$ & $20.43 \pm 0.33$ & $56.33 \pm 6.12$ & $61.70 \pm 3.57$ & $30.93 \pm 0.98$ & $47.09 \pm 1.87$ \\
High cholesterol diet & $53.30 \pm 3.07^{*}$ & $35.71 \pm 1.87^{*}$ & $93.30 \pm 4.94^{*}$ & $125.33 \pm 13.94^{*}$ & $24.87 \pm 1.54^{*}$ & $80.72 \pm 3.19^{*}$ \\
Rutin (0.2\%) + HCD & $37.60 \pm 2.00^{*}$ & $23.10 \pm 1.25 \#$ & $86.46 \pm 5.25^{*}$ & $98.06 \pm 7.06^{* \#}$ & $26.86 \pm 1.35$ & $71.50 \pm 2.93^{* \#}$ \\
\hline
\end{tabular}

Data were expressed as Mean \pm SEM. *\&\# indicate a significant change from control and HCD, respectively, at $p<0.05$ using ANOVA followed by Tukey-Kramer as a post ANOVA test. Six animals were used in each group. 
Table 3 Effect of High cholesterol diet, rutin and their combination on levels of MDA, GSH and $\mathrm{H} 2 \mathrm{O} 2$

\begin{tabular}{cccc}
\hline Group & MDA (mmol/g) & GSH $(\mathbf{n m o l} / \mathbf{1 0 0 m g})$ & H2O2 $(\boldsymbol{\mu M})$ \\
\hline $\begin{array}{c}\text { Control (rat chow) } \\
\text { Rutin (0.2\%) }\end{array}$ & $256 \pm 7.21$ & $171.91 \pm 7.48$ & $1.3 \pm 0.6$ \\
$\begin{array}{c}\text { High cholesterol } \\
\text { diet }\end{array}$ & $315.34 \pm 6.50 \pm 7.49$ & $170.53 \pm 4.06$ & $1.1 \pm 0.43$ \\
& & $143.07 \pm 2.16^{*}$ & $5.9 \pm 1.1^{*}$ \\
Rutin (0.2\%) + HCD & $263.56 \pm 9.02^{* \#}$ & $192.87 \pm 4.22^{* \#}$ & $1.8 \pm 0.98^{\#}$ \\
\hline
\end{tabular}

Data were expressed as Mean \pm SEM. *\&\# indicate a significant change from control and HCD, respectively, at $p<0.05$ using ANOVA followed by TukeyKramer as a post ANOVA test. Six animals were used in each group.

The persistent oxidative stress causes DNA mutation and increases fibroblastic activity, leading to liver cirrhosis and carcinoma. Previous study has demonstrated that rutin has a protective effect against $\mathrm{HCD}$-induced liver cirrhosis [50]. Lipid alterations have been considered as contributory factors to oxidative stress in obesity resulted
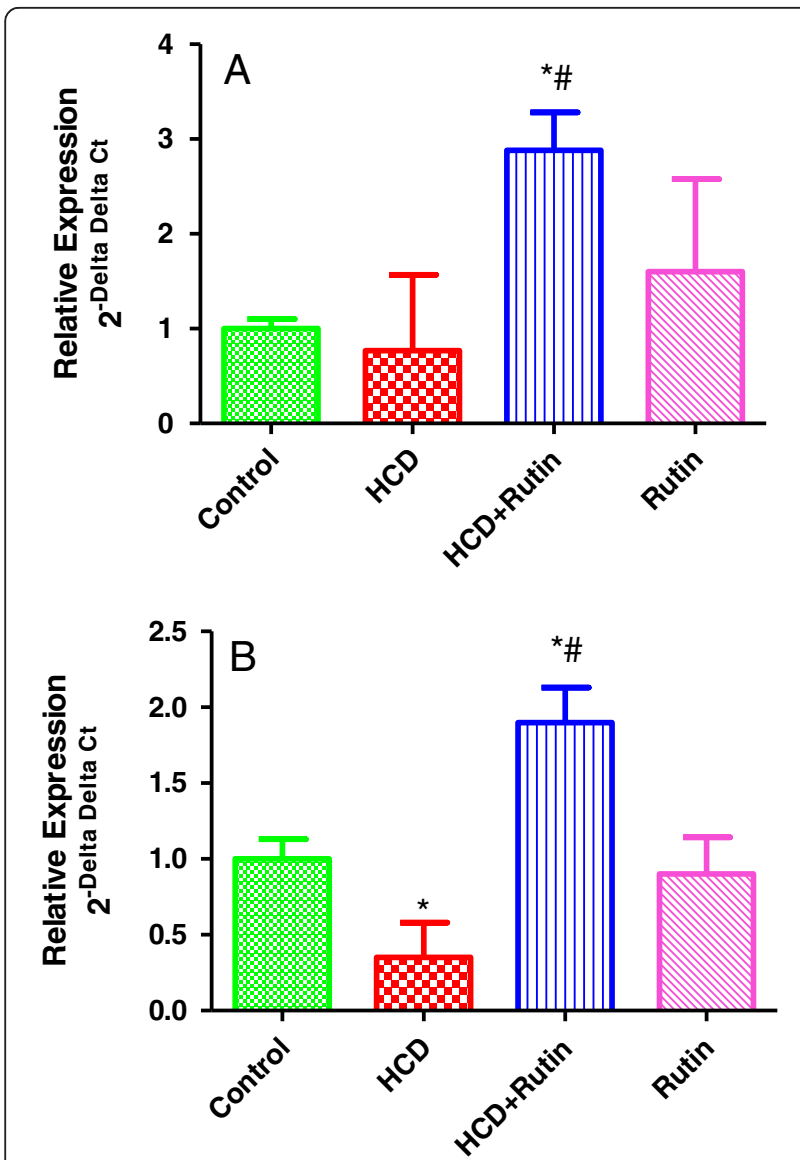

Figure 1 Showing the Effect of HCD, rutin, and their combination on the expression levels of Glutathione peroxidase $(A)$ and Glutathione reductase (B) in rat liver. Data were presented as mean \pm SEM $(n=6)$. ${ }^{*}$ and \# indicate significant change from control and $\mathrm{HCD}$, respectively, at $\mathrm{P}<0.05$ using ANOVA followed by TukeyKramer as a post ANOVA test. of increased in the production of ROS as well as reduced antioxidant enzymes [53,54]. Reactive oxygen species and lipid peroxidation products impaired the respiratory chain in hepatocytes through oxidative damage to the mitochondrial DNA. In the present study, HCD feeding resulted in increasing the levels of TG, TC and LDL and decreasing in HDL as compared with control group; our finding was in agreement with other studies [55,56].

High cholesterol diet leads to dyslipidemic syndrome and hyperlipidemia that characterized by increasing in TG and decreased in HDL-Cholesterol. [57]. Dyslipidemic syndrome produced anti-inflammatory effects by inhibiting the expressions of proinflammatory cytokines [58,59]. In the present study, rutin-supplement attenuated HCDinduced hepatotoxicity by lowering the concentrations of TC, TG and LDL. Similarly, rutin lowers the lipid components in the serum of hyper-cholesterolemic rats, probably by reducing the activity of 3-hydroxy-3-methyl-glutarylCoA reductase [60]. This may be explained on the basis that rutin has a strong ability to chelate multivalent metal ions, especially zinc, calcium and iron [39].

Lipid peroxidation is characterized by imbalance between oxidant-antioxidant and ROS are thought to be a component of obesity-induced pathology [61,62]. The data of this study showed that HCD increased lipid peroxidation in hepatic tissue as expressed by increased tissue levels of MDA, this will cause an increased accumulation of $\mathrm{H}_{2} \mathrm{O}_{2}$ which could further stimulate lipid peroxidation. The present results were convenient with earlier studies $[62,63]$ showed that obesity is an independent risk factor for increasing lipid peroxidation and decreased activity of cytoprotective enzymes. Damage, at the cellular level by oxidative stress, is attenuated by antioxidant enzyme such as PON-1, GSHPx, GPx, GR and Glutathione $S$ transferase $\alpha$, sulfiredoxin and glutamate-cystein ligase. When the balance between ROS production and antioxidant defense is lost oxidative stress occurred through a serious of events deregulates the cellular functions leading various pathological conditions [26].

The GSH antioxidant system plays critical role in the detoxification process of liver and is involved in overcoming various hepatotoxins-induced liver injuries [64]. The increasing GSH levels can protect cells against oxidative damage, while depleting cellular GSH can promote such injury $[65,66]$. Our results showed that GSH level was decreased in HCD fed rats compared to control which was in agreement with other [67]. The cellular roles of GR have been broadened in various physiological phenomena, especially cellular response against many kinds of stresses by reducing glutathione disulfide (GSSG) to the sulfhydryl form GSH which is an important cellular antioxidant [68]. Glutathione peroxidase is a selenoenzyme, which catalyzes the reduction in hydrogen peroxide to 


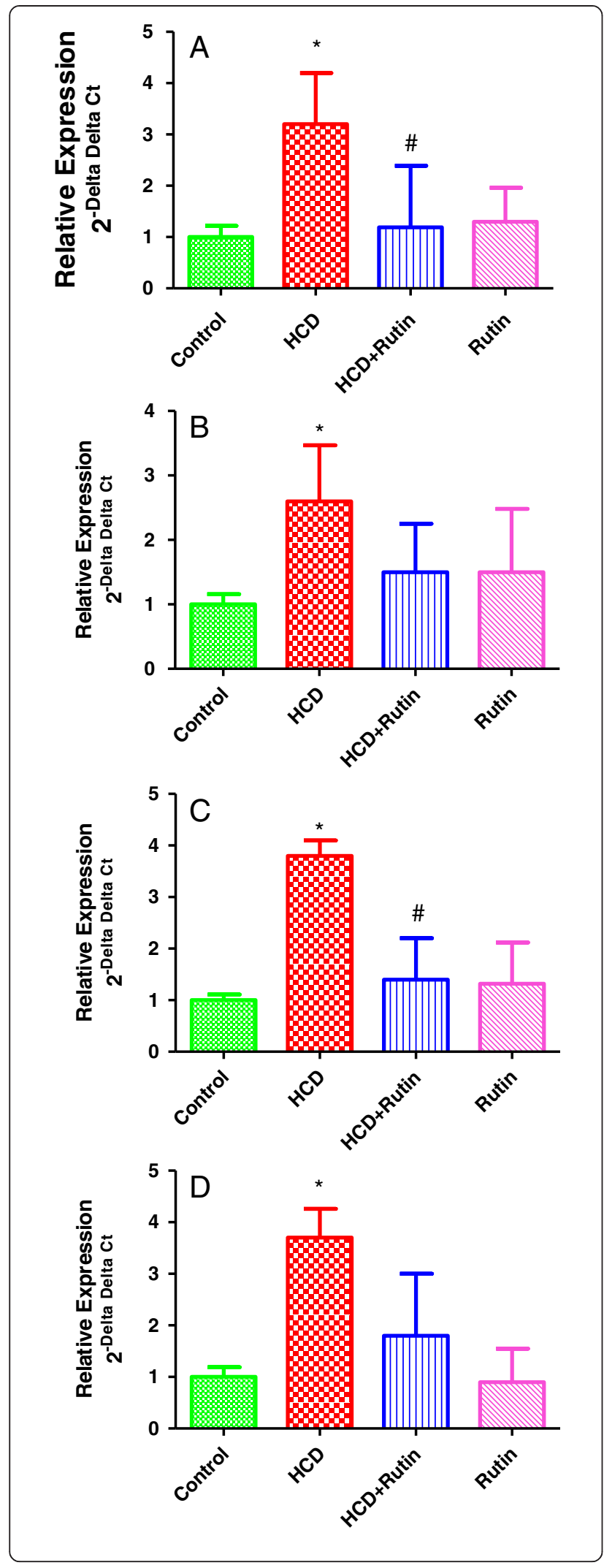

Figure 2 Showing the Effect of $\mathrm{HCD}$, rutin, and their combination on the expression levels of Glutathione $S$ transferase a $(A)$, paraoxonase-1 (B), sulfiredoxin (C) and glutamate-cystein ligase $(D)$ in rat liver tissues. Data were presented as mean \pm SEM $(n=6) .{ }^{*}$ and \# indicate significant change from control and HCD, respectively, at $\mathrm{P}<0.05$ using ANOVA followed by Tukey-Kramer as a post ANOVA test.

$\mathrm{H}_{2} \mathrm{O}$ and oxidizing GSH into GSSG [69]. Down-regulation of GR results in cellular GSSG content increase, and reduction of GSH/GSSG ratio is involved in many responses against oxidative stress. Our results showed decrease in GR and GPx genes expression in liver tissues of HCD fed rats and were in agreement with others [70,71]. Rutin supplementation led to increase the expression of these genes in liver tissues. These data showed that HCD not only increase the free radical formation but also decrease its ability to detoxify ROS, which lead to hepatocellular damage [72].

Paraoxonase-1 (PON-1), an enzyme with lactonase and esterase activities, is synthesized mainly by the liver $[73,74]$ and it plays a role in the regulation of oxidative stress, fibrosis and hepatic cell apoptosis in chronic liver diseases. [75]. The present results showed that the HCD feeding significantly overexpressed the expression of PON-1 in liver tissues. This increase in the expression enhanced the sensitivity to liver damage development. The increasing in PON-1 hepatic expression in chronic hepatitis and liver cirrhosis, probably as a response to the enhanced oxidative stress observed in the earliest stages of these diseases [75]. Our results were disagreement with Zhang et al., who proposed that PON-1 over expression provides strong protection against the development of experimental liver disease [76]. Rutin supplementation led to decrease the expression of PON-1 gene in liver tissues, and this attributed to its effect as an antioxidant and reduced oxidative stress in plasma, liver and other organs $[51,77]$. The present finding was in agreement with recent study who found that rutin administered to High fat diet fed rats attenuated the diet-induced metabolic syndrome, NASH, and cardiovascular abnormalities [78].

Glutamate-cysteine ligase catalyzes the biosynthesis of cellular GSH and is considered one of antioxidant system for counteracting ROS produced during oxidative stress injury. Sulfiredoxin-1 (Srx1), an antioxidant, contains a C-terminal cysteine residue that is highly conserved and crucial for its antioxidant function [79,80]. It plays a key role in cellular responses to oxidative stress by restoring the activity of over-oxidized peroxiredoxins [80,81]. The results of the present study show that Srx1, GCL and GST $\alpha$ expressions are selectively up-regulated in liver tissues of rat fed with $\mathrm{HCD}$. Reactive oxygen species elicit many different responses depending upon the severity of the damage and the duration of the exposure [82]. 
Low doses of ROS activate c-jun N-terminal Kinase (JNK) transiently thereby promoting cell proliferation. However, persistent JNK activation due to severe oxidative stress ultimately causes cell death via activation of pro-apoptotic signaling pathway $[83,84]$. In the current study the activation of GST $\alpha$ was due to the modulations of GST levels on JNK activation by formation of GST $\alpha$-JNK complex integrity in sequence to inhibit its activation. Our results was in agreement with other studies $[85,86]$, who shows that, besides detoxification of GST- $\alpha$, it plays an important role in signaling events by modulating stress cell signaling kinases in particular through inhibition of JNK activation. The upregulation of GCL in our data was in agreement with Nishiya et al., who found that, marked upregulation of GCL gene in rats treated with tienilic acid induced hepatotoxicity [87]. Similarly, $\mathrm{Wu}$ and his colleague found that $\mathrm{Cd}-$ induced oxidative stress increased the mRNA expression of GCL with graded Nrf2 activation. [88]. However, the present data is disagreement with Wang and his colleagues; they found that the downregulation of GCL is confirmed the damage of liver cells in mice treated with Dioscorea bulbifera rhizome [89]. The up-regulation of Sxr1 to maintains the balance between $\mathrm{H} 2 \mathrm{O} 2$ production and elimination and then protects liver cells from apoptosis; our finding was in agreement with previous study [90]. In the present study rutin administration reversed the changes induced by HCD feeding in rats to normal levels probably by reducing oxidative stress and inflammation in liver tissue.

\section{Conclusion}

The high-cholesterol diet induces symptoms of metabolic syndrome in rat including hepatotoxicity with alteration in the oxidative stress markers. Rutin reversed the changes induced by HCD probably by reducing the oxidative stress and inflammation in the liver. Therefore the administration of rutin may be used as an antioxidant in decreasing the hepatic stress in humans as a treatment.

\section{Competing interests}

The authors declare that they have no competing interests.

\section{Authors' contributions}

$\mathrm{SA}, \mathrm{HA}$ and $\mathrm{MA}$, equally participated in the dietary protocol design of the experimental groups and performed the biochemical assays and their statistical analysis and shared in drafted the manuscript. MH performed al the molecular studies and their statistical analysis and shared in draft the manuscript. AA, MS, OA and KA shared in the draft the manuscript. All authors read and approved the final manuscript.

\section{Acknowledgements}

The authors extend their appreciation to the Deanship of Scientific Research at King Saud University for funding this work through the research group project no. RGP-VPP-179.

Received: 25 January 2013 Accepted: 13 June 2013

Published: 17 June 2013

\section{References}

1. Farrell GC, Teoh NC, McCuskey RS: Hepatic microcirculation in fatty liver disease. Anat Rec (Hoboken) 2008, 291:684-692.

2. Trauner M, Arrese M, Wagner M: Fatty liver and lipotoxicity. Biochim Biophys Acta 1801, 2010:299-310.

3. Bellentani S, Saccoccio G, Masutti F, Croce LS, Brandi G, Sasso F, Cristanini G, Tiribelli C: Prevalence of and risk factors for hepatic steatosis in Northern Italy. Ann Intern Med 2000, 132:112-117.

4. Vitaglione P, Morisco F, Mazzone G, Amoruso DC, Ribecco MT, Romano A, Fogliano V, Caporaso N, D'Argenio G: Coffee reduces liver damage in a rat model of steatohepatitis: the underlying mechanisms and the role of polyphenols and melanoidins. Hepatology 2010, 52:1652-1661.

5. Araya J, Rodrigo R, Videla LA, Thielemann L, Orellana M, Pettinelli $P$, Poniachik J: Increase in long-chain polyunsaturated fatty acid $n-6 / n-3$ ratio in relation to hepatic steatosis in patients with non-alcoholic fatty liver disease. Clin Sci (Lond) 2004, 106:635-643.

6. Araya J, Rodrigo R, Pettinelli P, Araya AV, Poniachik J, Videla LA: Decreased liver fatty acid delta- 6 and delta- 5 desaturase activity in obese patients. Obesity (Silver Spring) 2010, 18:1460-1463.

7. Videla LA, Rodrigo R, Araya J, Poniachik J: Insulin resistance and oxidative stress interdependency in non-alcoholic fatty liver disease. Trends $\mathrm{Mol}$ Med 2006, 12:555-558.

8. Tomofuji T, Azuma T, Kusano H, Sanbe T, Ekuni D, Tamaki N, Yamamoto T, Watanabe T: Oxidative damage of periodontal tissue in the rat periodontitis model: effects of a high-cholesterol diet. FEBS Lett 2006, 580:3601-3604.

9. Fried M, Hainer V, Basdevant A, Buchwald H, Dietel M, Finer N, Greve JW, Horber F, Mathus-Vliegen E, Scopinaro N, et al: Interdisciplinary European guidelines on surgery for severe obesity. Rozhl Chir 2008, 87:468-476.

10. Preiss D, Sattar N: Non-alcoholic fatty liver disease: an overview of prevalence, diagnosis, pathogenesis and treatment considerations. Clin Sci (Lond) 2008, 115:141-150.

11. Al-Nozha MM, Al-Mazrou YY, Al-Maatouq MA, Arafah MR, Khalil MZ, Khan NB, Al-Marzouki K, Abdullah MA, Al-Khadra AH, Al-Harthi SS, et al: Obesity in Saudi Arabia. Saudi Med J 2005, 26:824-829.

12. Al-hamoudi W, El-Sabbah M, Ali S, Altuwaijri M, Bedewi M, Adam M, Alhammad A, Sanai F, Alswat K, Abdo A: Epidemiological, clinical, and biochemical characteristics of Saudi patients with nonalcoholic fatty liver disease: a hospital-based study. Ann Saudi Med 2012, 32:288-292.

13. Jump DB: N-3 polyunsaturated fatty acid regulation of hepatic gene transcription. Curr Opin Lipidol 2008, 19:242-247.

14. Clarke SD, Jump DB: Polyunsaturated fatty acid regulation of hepatic gene transcription. Lipids 1996, 31(Suppl):S7-S11.

15. Pegorier JP, Le May C, Girard J: Control of gene expression by fatty acids. J Nutr 2004, 134:2444S-2449S.

16. Nguyen P, Leray V, Diez M, Serisier S, Le Bloc'h J, Siliart B, Dumon H: Liver lipid metabolism. J Anim Physiol Anim Nutr 2008, 92:272-283.

17. Ikonen E: Mechanisms for cellular cholesterol transport: defects and human disease. Physiol Rev 2006, 86:1237-1261.

18. Ho YK, Brown MS, Goldstein JL: Hydrolysis and excretion of cytoplasmic cholesteryl esters by macrophages: stimulation by high density lipoprotein and other agents. J Lipid Res 1980, 21:391-398.

19. Sonta T, Inoguchi T, Tsubouchi H, Sekiguchi N, Kobayashi K, Matsumoto S, Utsumi $\mathrm{H}$, Nawata $\mathrm{H}$ : Evidence for contribution of vascular $\mathrm{NAD}(\mathrm{P}) \mathrm{H}$ oxidase to increased oxidative stress in animal models of diabetes and obesity. Free Radic Biol Med 2004, 37:115-123.

20. Furukawa S, Fujita T, Shimabukuro M, Iwaki M, Yamada Y, Nakajima Y, Nakayama O, Makishima M, Matsuda M, Shimomura I: Increased oxidative stress in obesity and its impact on metabolic syndrome. J Clin Invest 2004, 114:1752-1761.

21. Faienza MF, Francavilla R, Goffredo R, Ventura A, Marzano F, Panzarino G, Marinelli G, Cavallo L, Di Bitonto G: Oxidative stress in obesity and metabolic syndrome in children and adolescents. Horm Res Paediatr 2012, 78:158-164.

22. Park S, Kim M, Paik JK, Jang YJ, Lee SH, Lee JH: Oxidative stress is associated with $\mathrm{C}$-reactive protein in non-diabetic postmenopausal women, independent of obesity and insulin resistance. Clin Endocrinol (Oxf) 2012, 79:65-70.

23. Mishra KP: Cell membrane oxidative damage induced by gammaradiation and apoptotic sensitivity. J Environ Pathol Toxicol Oncol 2004, 23:61-66.

24. Bravo E, Palleschi S, Aspichueta P, Buque X, Rossi B, Cano A, Napolitano M, Ochoa B, Botham KM: High fat diet-induced non alcoholic fatty liver disease 
in rats is associated with hyperhomocysteinemia caused by down regulation of the transsulphuration pathway. Lipids Health Dis 2011, 10:60.

25. Koc A, Duru M, Ciralik H, Akcan R, Sogut S: Protective agent, erdosteine, against cisplatin-induced hepatic oxidant injury in rats. Mol Cell Biochem 2005, 278:79-84

26. Blokhina O, Virolainen E, Fagerstedt KV: Antioxidants, oxidative damage and oxygen deprivation stress: a review. Ann Bot 2003, 91:Spec No:179-Spec No:194

27. Yagmurca M, Bas O, Mollaoglu H, Sahin O, Nacar A, Karaman O, Songur A: Protective effects of erdosteine on doxorubicin-induced hepatotoxicity in rats. Arch Med Res 2007, 38:380-385.

28. Sayed-Ahmed AMA MM, Al-Rejaie SS, Al-Yahya AA, Al-Shabanah OA, Hafez MM Nagi MN: Thymoquinone attenuates diethylnitrosamine induction of hepatic carcinogenesis through antioxidant signaling. Oxidative Medicine and Cellular Longevity 2010, 3:254-261

29. Danz ED, Skramsted J, Henry N, Bennett JA, Keller RS: Resveratrol prevents doxorubicin cardiotoxicity through mitochondrial stabilization and the Sirt1 pathway. Free Radic Biol Med 2009, 46:1589-1597.

30. Fisher-Wellman K, Bell HK, Bloomer RJ: Oxidative stress and antioxidant defense mechanisms linked to exercise during cardiopulmonary and metabolic disorders. Oxid Med Cell Longev 2009, 2:43-51.

31. Senti M, Tomas M, Fito M, Weinbrenner T, Covas MI, Sala J, Masia R, Marrugat J: Antioxidant paraoxonase 1 activity in the metabolic syndrome. J Clin Endocrinol Metab 2003, 88:5422-5426.

32. Peltoniemi MJ, Rytila PH, Harju TH, Soini YM, Salmenkivi KM, Ruddock LW, Kinnula VL: Modulation of glutaredoxin in the lung and sputum of cigarette smokers and chronic obstructive pulmonary disease. Respir Res 2006, 7:133.

33. Lu W, Chen Z, Zhang H, Wang Y, Luo Y, Huang P: ZNF143 transcription factor mediates cell survival through upregulation of the GPX1 activity in the mitochondrial respiratory dysfunction. Cell Death Dis 2012, 3:e422.

34. Potter JD: Cancer prevention: epidemiology and experiment. Cancer Lett 1997, 114:7-9

35. Aleksandrov PN, Speranskaia TV, Bobkov lu G, Zagorevskii VA, Zykov DA: [Effect of rutin and esculamine on models of aseptic inflammation]. Farmakol Toksikol 1986, 49:84-86.

36. Deschner EE, Ruperto J, Wong G, Newmark HL: Quercetin and rutin as inhibitors of azoxymethanol-induced colonic neoplasia. Carcinogenesis 1991, 12:1193-1196.

37. Bear WL, Teel RW: Effects of citrus flavonoids on the mutagenicity of heterocyclic amines and on cytochrome P450 1A2 activity. Anticancer Res 2000, 20:3609-3614

38. Chen S, Gong J, Liu F, Mohammed U: Naturally occurring polyphenolic antioxidants modulate IgE-mediated mast cell activation. Immunology 2000, 100:471-480

39. Khan RA, Khan MR, Sahreen S: CCI4-induced hepatotoxicity: protective effect of rutin on p53, CYP2E1 and the antioxidative status in rat. BMC Complement Altern Med 2012, 12:178.

40. Lopez-Revuelta A, Sanchez-Gallego Jl, Hernandez-Hernandez A, Sanchez-Yague J, Llanillo M: Membrane cholesterol contents influence the protective effects of quercetin and rutin in erythrocytes damaged by oxidative stress. Chem Biol Interact 2006, 161:79-91.

41. Takashi N, Nobuaki T, Yoshiaki I, Naoyuki N: Suppression of early and advanced glycation by dietary water-soluble rutin derivative in diabetic rats. Int Congr Ser 2002, 1245:403-405.

42. Al-Rejaie SS, Abuohashish HM, Alkhamees OA, Aleisa AM, Alroujayee AS: Gender difference following high cholesterol diet induced renal injury and the protective role of rutin and ascorbic acid combination in Wistar albino rats. Lipids Health Dis 2012, 11:41

43. Ohkawa H, Ohishi N, Yagi K: Assay for lipid peroxides in animal tissues by thiobarbituric acid reaction. Anal Biochem 1979, 95:351-358.

44. Sedlak J, Lindsay RH: Estimation of total, protein-bound, and nonprotein sulfhydryl groups in tissue with Ellman's reagent. Anal Biochem 1968, 25:192-205.

45. Sayed-Ahmed MM, Al-Shabanah OA, Hafez MM, Aleisa AM, Al-Rejaie SS: Inhibition of gene expression of heart fatty acid binding protein and organic cation/carnitine transporter in doxorubicin cardiomyopathic rat model. Eur J Pharmacol 2010, 640:143-149.

46. Artham SM, Lavie CJ, Milani RV, Ventura HO: The obesity paradox: impact of obesity on the prevalence and prognosis of cardiovascular diseases. Postgrad Med 2008, 120:34-41.
47. Madsen AN, Hansen G, Paulsen SJ, Lykkegaard K, Tang-Christensen M, Hansen HS, Levin BE, Larsen PJ, Knudsen LB, Fosgerau K, et al: Long-term characterization of the diet-induced obese and diet-resistant rat model: a polygenetic rat model mimicking the human obesity syndrome. J Endocrinol 2010, 206:287-296

48. Lopez IP, Marti A, Milagro Fl, Zulet Md Mde L, Moreno-Aliaga MJ, Martinez JA, De Miguel C: DNA microarray analysis of genes differentially expressed in diet-induced (cafeteria) obese rats. Obes Res 2003, 11:188-194.

49. Tan M, Schmidt RH, Beier JI, Watson WH, Zhong H, States JC, Arteel GE: Chronic subhepatotoxic exposure to arsenic enhances hepatic injury caused by high fat diet in mice. Toxicol Appl Pharmacol 2011, 257:356-364.

50. Song HY, Mao ZM, Yang LL, Liu T, Li DF, Zhang L, Ge YL, Zheng PY, Liu P, Zhang $X Q$, et al: Dangfei liganning capsules attenuate the susceptibility of rat nonalcoholic fatty liver to carbon tetrachloride toxicity. J Tradit Chin Med 2011, 31:327-333.

51. Kamalakkannan N, Prince PS: Antihyperglycaemic and antioxidant effect of rutin, a polyphenolic flavonoid, in streptozotocin-induced diabetic wistar rats. Basic Clin Pharmacol Toxicol 2006, 98:97-103.

52. Kamalakkannan N, Stanely Mainzen Prince P: Rutin improves the antioxidant status in streptozotocin-induced diabetic rat tissues. Mol Cell Biochem 2006, 293:211-219.

53. Tsimikas S, Miller Yl: Oxidative modification of lipoproteins: mechanisms, role in inflammation and potential clinical applications in cardiovascular disease. Curr Pharm Des 2011, 17:27-37.

54. Lavie L, Lavie P: Molecular mechanisms of cardiovascular disease in OSAHS: the oxidative stress link. Eur Respir J 2009, 33:1467-1484

55. Noeman SA, Hamooda HE, Baalash AA: Biochemical study of oxidative stress markers in the liver, kidney and heart of high fat diet induced obesity in rats. Diabetol Metab Syndr 2011, 3:17.

56. Amin KA, Nagy MA: Effect of Carnitine and herbal mixture extract on obesity induced by high fat diet in rats. Diabetol Metab Syndr 2009, 1:17.

57. Bloomgarden ZT: Dyslipidemia and the metabolic syndrome. Diabetes Care 2004, 27:3009-3016.

58. Kauss T, Moynet D, Rambert J, Al-Kharrat A, Brajot S, Thiolat D, Ennemany R, Fawaz F, Mossalayi MD: Rutoside decreases human macrophage-derived inflammatory mediators and improves clinical signs in adjuvant-induced arthritis. Arthritis Res Ther 2008, 10:R19.

59. Guardia $T$, Rotelli $A E$, Juarez AO, Pelzer LE: Anti-inflammatory properties of plant flavonoids. Effects of rutin, quercetin and hesperidin on adjuvant arthritis in rat. Farmaco 2001, 56:683-687.

60. Ziaee A, Zamansoltani F, Nassiri-Asl M, Abbasi E: Effects of rutin on lipid profile in hypercholesterolaemic rats. Basic Clin Pharmacol Toxicol 2009, 104:253-258.

61. Park S, Park NY, Valacchi G, Lim Y: Calorie restriction with a high-fat diet effectively attenuated inflammatory response and oxidative stressrelated markers in obese tissues of the high diet fed rats. Mediators Inflamm 2012, 2012:984643.

62. Huisamen B, Dietrich D, Bezuidenhout N, Lopes J, Flepisi B, Blackhurst D, Lochner A: Early cardiovascular changes occurring in diet-induced, obese insulin-resistant rats. Mol Cell Biochem 2012, 368:37-45.

63. Vincent HK, Powers SK, Dirks AJ, Scarpace PJ: Mechanism for obesityinduced increase in myocardial lipid peroxidation. Int J Obes Relat Metab Disord 2001, 25:378-388.

64. Husain K, Somani SM: Interaction of exercise training and chronic ethanol ingestion on hepatic and plasma antioxidant system in rat. J App/ Toxicol 1997, 17:189-194.

65. Ji L, Liu T, Chen Y, Wang Z: Protective mechanisms of N-acetyl-cysteine against pyrrolizidine alkaloid clivorine-induced hepatotoxicity. J Cell Biochem 2009, 108:424-432.

66. Chen L, Pan DD, Zhou J, Jiang YZ: Protective effect of seleniumenriched Lactobacillus on CCl4-induced liver injury in mice and its possible mechanisms. World journal of gastroenterology: WJG 2005, 11:5795-5800

67. Sanz N, Diez-Fernandez C, Alvarez A, Cascales M: Age-dependent modifications in rat hepatocyte antioxidant defense systems. J Hepatol 1997, 27:525-534

68. Kim SJ, Jung HJ, Hyun DH, Park EH, Kim YM, Lim CJ: Glutathione reductase plays an anti-apoptotic role against oxidative stress in human hepatoma cells. Biochimie 2010, 92:927-932.

69. Tappel AL: Glutathione peroxidase and hydroperoxides. Methods Enzymol 1978, 52:506-513. 
70. Sekine Y, Osei-Hwedieh D, Matsuda K, Raghavachari N, Liu D, Furuya Y, Koike H, Suzuki K, Remaley AT: High fat diet reduces the expression of glutathione peroxidase 3 in mouse prostate. Prostate 2011, 71:1499-1509.

71. De Haan JB, Witting PK, Stefanovic N, Pete J, Daskalakis M, Kola I, Stocker R Smolich JJ: Lack of the antioxidant glutathione peroxidase-1 does not increase atherosclerosis in C57BL/J6 mice fed a high-fat diet. J Lipid Res 2006, 47:1157-1167.

72. Pradeep K, Mohan CV, Gobianand K, Karthikeyan S: Silymarin modulates the oxidant-antioxidant imbalance during diethylnitrosamine induced oxidative stress in rats. Eur J Pharmacol 2007, 560:110-116.

73. Leviev I, Negro F, James RW: Two alleles of the human paraoxonase gene produce different amounts of mRNA. An explanation for differences in serum concentrations of paraoxonase associated with the (Leu-Met54) polymorphism. Arterioscler Thromb Vasc Biol 1997, 17:2935-2939.

74. Rodrigo L, Gil F, Hernandez AF, Marina A, Vazquez J, Pla A: Purification and characterization of paraoxon hydrolase from rat liver. Biochem J 1997, 321(Pt 3):595-601

75. Ferre N, Marsillach J, Camps J, Mackness B, Mackness M, Riu F, Coll B, Tous $M$, Joven J: Paraoxonase-1 is associated with oxidative stress, fibrosis and FAS expression in chronic liver diseases. J Hepatol 2006, 45:51-59.

76. Zhang C, Peng W, Jiang X, Chen B, Zhu J, Zang Y, Zhang J, Zhu T, Qin J: Transgene expression of human PON1 Q in mice protected the liver against CCI4-induced injury. J Gene Med 2008, 10:94-100.

77. Curin Y, Ritz MF, Andriantsitohaina R: Cellular mechanisms of the protective effect of polyphenols on the neurovascular unit in strokes. Cardiovasc Hematol Agents Med Chem 2006, 4:277-288.

78. Panchal SK, Poudyal H, Arumugam TV, Brown L: Rutin attenuates metabolic changes, nonalcoholic steatohepatitis, and cardiovascular remodeling in high-carbohydrate, high-fat diet-fed rats. J Nutr 2011, 141:1062-1069.

79. Findlay VJ, Tapiero H, Townsend DM: Sulfiredoxin: a potential therapeutic agent? Biomedicine \& pharmacotherapy = Biomedecine \& pharmacotherapie 2005, 59:374-379.

80. Rhee SG, Jeong W, Chang TS, Woo HA: Sulfiredoxin, the cysteine sulfinic acid reductase specific to 2-Cys peroxiredoxin: its discovery, mechanism of action, and biological significance. Kidney Int Suppl 2007:S3-S8.

81. Biteau B, Labarre J, Toledano MB: ATP-dependent reduction of cysteinesulphinic acid by S. cerevisiae sulphiredoxin. Nature 2003, 425:980-984

82. Martindale JL, Holbrook NJ: Cellular response to oxidative stress: signaling for suicide and survival. J Cell Physiol 2002, 192:1-15.

83. Maher $P, S$ Schubert D: Signaling by reactive oxygen species in the nervous system. Cell Mol Life Sci 2000, 57:1287-1305.

84. Feinendegen LE: Reactive oxygen species in cell responses to toxic agents. Hum Exp Toxicol 2002, 21:85-90.

85. Turella P, Cerella C, Filomeni G, Bullo A, De Maria F, Ghibelli L, Ciriolo MR, Cianfriglia M, Mattei M, Federici $G$, et al: Proapoptotic activity of new glutathione S-transferase inhibitors. Cancer Res 2005, 65:3751-3761.

86. Burg D, Riepsaame J, Pont C, Mulder G, van de Water B: Peptide-bond modified glutathione conjugate analogs modulate GSTpi function in GSH-conjugation, drug sensitivity and JNK signaling. Biochem Pharmacol 2006, 71:268-277.

87. Nishiya T, Mori K, Hattori C, Kai K, Kataoka H, Masubuchi N, Jindo T, Manabe $\mathrm{S}$ : The crucial protective role of glutathione against tienilic acid hepatotoxicity in rats. Toxicol Appl Pharmacol 2008, 232:280-291.

88. Wu KC, Liu JJ, Klaassen CD: Nrf2 activation prevents cadmium-induced acute liver injury. Toxicol Appl Pharmacol 2012, 263:14-20.

89. Wang J, Ji L, Liu H, Wang Z: Study of the hepatotoxicity induced by Dioscorea bulbifera L. rhizome in mice. Biosci Trends 2010, 4:79-85.

90. Baek JY, Han SH, Sung SH, Lee HE, Kim YM, Noh YH, Bae SH, Rhee SG, Chang TS: Sulfiredoxin protein is critical for redox balance and survival of cells exposed to low steady-state levels of H2O2. J Biol Chem 2012, 287:81-89.

doi:10.1186/1472-6882-13-136

Cite this article as: Al-Rejaie et al:: Protective effect of rutin on the antioxidant genes expression in hypercholestrolemic male Westar rat. BMC Complementary and Alternative Medicine 2013 13:136.

\section{Submit your next manuscript to BioMed Central and take full advantage of:}

- Convenient online submission

- Thorough peer review

- No space constraints or color figure charges

- Immediate publication on acceptance

- Inclusion in PubMed, CAS, Scopus and Google Scholar

- Research which is freely available for redistribution

Submit your manuscript at www.biomedcentral.com/submit
Biomed Central 